University for Business and Technology in Kosovo

UBT Knowledge Center

UBT International Conference

2012 UBT International Conference

Nov 2nd, 9:00 AM - Nov 3rd, 5:00 PM

\title{
Initiatives on Urban Transformation in South-East Europe: case Prishtina
}

Florina Jerliu

University of Prishtina, florinajerliu@gmail.com

Follow this and additional works at: https://knowledgecenter.ubt-uni.net/conference

Part of the Architecture Commons

\section{Recommended Citation}

Jerliu, Florina, "Initiatives on Urban Transformation in South-East Europe: case Prishtina" (2012). UBT International Conference. 11.

https://knowledgecenter.ubt-uni.net/conference/2012/all-events/11

This Event is brought to you for free and open access by the Publication and Journals at UBT Knowledge Center. It has been accepted for inclusion in UBT International Conference by an authorized administrator of UBT Knowledge Center. For more information, please contact knowledge.center@ubt-uni.net. 


\title{
Initiatives on urban transformation in South-East Europe: case Prishtina
}

\author{
Florina Jerliu, Dipl.Eng.Arch, MA, PhD.cand. \\ Assistant, Faculty of Civil Engineering and Architecture, \\ Department of Architecture, University of Prishtina \\ florinajerliu@gmail.com
}

\begin{abstract}
Countries forming the South East Europe (SEE) face common post-socialist and/or pos-war challenges since 1990s. Among issues identified in SEE is the rapid transformation of physical environment between early 1990s and today. More specifically, unchecked urban development has been identified as a common challenge in the region, and as such, it has drawn the attention of a wider Europe. Being committed to upgrade urban situations, a number of initiatives, both governmental and nongovernmental, have been created and jointly initiated regional projects for devising solutions in local level that may apply in a wider regional context. The criticism about urban occurrences in SEE, developed by such initiatives has played and important role in raising the awareness about the complexity and the need to address the SEE context within the context of Europe as a whole. This paper documents initiatives for urban interventions in SEE by focusing in projects' developed in Prishtina, through cooperation with regional and international experts. In the light of this engagement, adequate steps need to be taken in order to foster respective legal frameworks devised through initiatives for urban interventions, along with implementation mechanisms, given that the physical and cultural environment is ranked high in Europe. Although studies on Prishtina became part of the official municipal program, there remains the need to harmonize the city vision with the development capacity and to adjust its development policies to suite the aspired sustainable development goals and global trends
\end{abstract}

Keywords: South East Europe, regional initiatives, urban transformation, unchecked development, urban intervention

\section{Introduction}

In the last two decades, former socialist countries that make the region of the Southeastern Europe and especially those that emerged out of wars in the former Yugoslav Federation have gone through immense political, social and economic transitions. During this period, the European agenda ranked high in state policies in the region, as it guarantees support in overcoming challenges of multiple transitions and investing in economic growth, social wellbeing, as well as acquiring the free movement within European developed countries. As alleged by the EU, all these countries "share the European perspective"53, which leads to the thought that with Albania, Bosnia and Herzegovina, Serbia, and Kosovo becoming candidate, and consequently, member states, the synonym and the reality of regional transition will come to an end. However, the ever-growing regional cooperation and networking has disclosed the fact that the transitional period takes longer, and that the fulfillment of the EU accession criteria doesn't guarantee by default the abruption of attitudes and capacities inherited from the former system, as well as progressive adaptation to the global trends. Until such transition is overcame and the developing level increases to optimal height, the South Eastern Europe (SEE) shall by default affect European agendas in issues which are crucial to the common institutional, physical and cultural environments.

\footnotetext{
53 http://www.southeast-europe.eu/eu-enlargement/potential-candidates.html
} 
Among challenges identified through networking initiatives in the region is the rapid transformation of physical environment between early 1990s and today. Descending practices in shaping urban areas, in many cases to the detriment of agricultural lands, and misuse of natural resources, remain a common denominator for the South East Europe, regardless of the EU membership status. More specifically, the unchecked urban development has been identified in almost all post-socialist and/or postwar countries in the region, and as such, it has drawn the attention of a wider Europe, and resulted in documents such is e.g. the "Vienna Declaration for informal settlement in SEE". Commitments that the SEE countries have taken in this respect, have been addressed and are gradually being met through model projects and initiatives coming from governments and the civil societies. Examples of such engagements are given in this paper in order to document findings and common challenges of urban transformations in SEE. Further more, the paper reveals strategies for improving urban situations through the example of Prishtina, capital city of Kosovo, which were devised through inventive cooperation projects and are being looked at to as possible replicable model.

\section{The context of urban transformation in SEE}

Although the geographical division of the South-East Europe (SEE) itself is not formally defined by $\mathrm{UN}^{54}$, the term itself has been widely adopted to identify the project designation area by cofinancing initiatives and regional networks as a substitute to the geographical and historical term for the Balkan, with the aim of coming as close as possible to the united Europe's cultural and political orientations. Despite of the number of countries (Figures 1-4) that do fall under this region, which commonly varies from nine to thirteen, depending on the regional co-funding and/or cooperation projects, as well as their EU membership status, the South Eastern Europe shares rather common challenges in terms of urban regeneration and development issues.
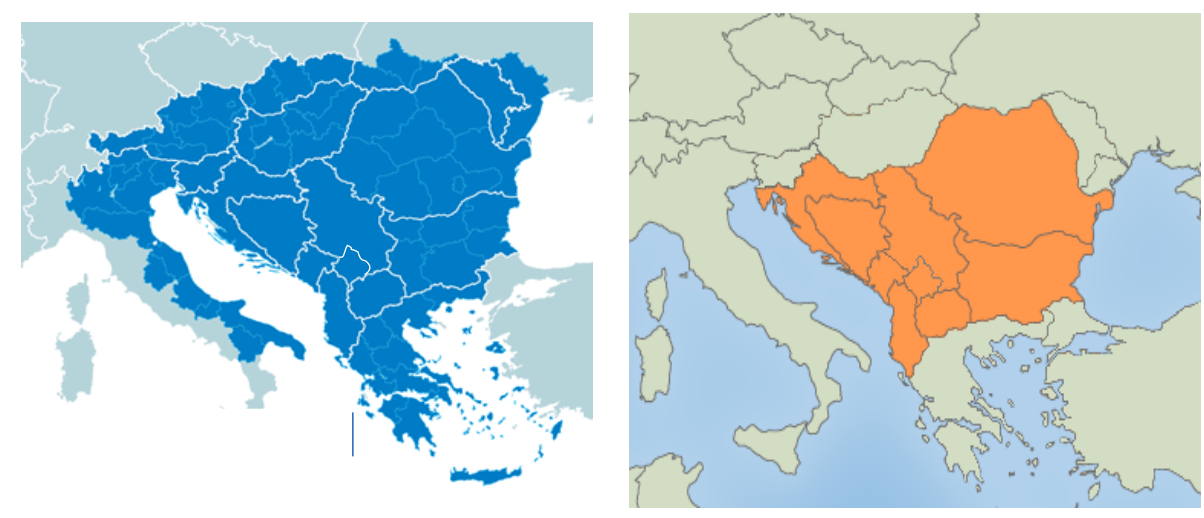

\footnotetext{
54 There is no formal reckognized geographical division of the Southeaster Europe. The Division provided by the United Nation s defines regions in Europe into Eastern, Western, Southern and Northern Europe. (see. http://unstats.un.org/unsd/methods/m49/m49regin.htm\#europe). The division created in late 1990s is programmatic and is linked with development co-funding such is the EU initiative called the Stability Pact for South Eastern Europe. The use of this term has grown and is gradually substituting the historical and geographical term of Balkan by the pretext of diminishing the negative connotation that has been generally associated with by the wester European countries.
} 
Figure 1. Geographical region of South-East Europe according to South-East Europe Transnational Cooperation Programme. The EU cofunded regional development model adds Austria, the eastern region of Italy and south-western Ukraine (as supporters). source: www.southeast-europe.net/en/
Figure 2. Geographically defined South-East Europe; countries that entirely fall under this region. Greece, Slovenia, Turkey take part in the region with pars of their territory. source:commons. wikimedia .org/wiki/File:Map_of_Sout honot Exmonn DNIT
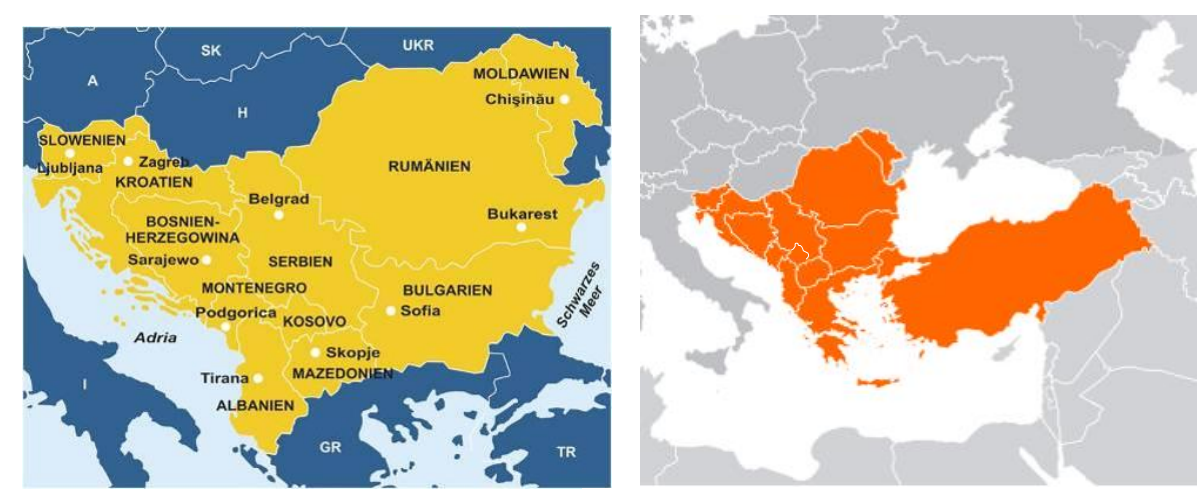

Figure 3. South-East Europe: Stability Pact member states. source: www.unigraz.at/en/hare 1 www/harelwww_t he region.htm/
Figure 4. South-East Europe: Southeast European Cooperation Process member states. source:http://www.answers.com topic/southeast-europeancooperation-process

Unchecked urban development has been identified as an issue in majority of SEE countries. Severe cases have been associated with urban growth caused by massive migration of rural population to urban centers that emerged in the very initial phase of post-war countries. In the case of Kosovo, it is estimated that only between years 1999 and 2001, the percentage of urban population increased from $37 \%$ to $44 \%{ }^{55}$. The increasing demands for land for housing in cities such is Prishtina (Figure 6) and in their outskirts have therefore subsequently affected their landscapes and environment in a larger scheme. This format of unplanned development continued in the following years in Kosovo as a consequence of weak law enforcement. The time pressure experienced during the adjustment of urban plans and the planning system as a whole in the new socio-economic context while coping with rural-urban migration is not only the feature of postwar cities. Such urban development trend is generally identified in countries that experienced the transition from the communist rule to market economy.

The pattern of unchecked development and the scope of obstruction that emerged inside urban areas are commonly identified in almost all capital cities. Variations derive depending on the inherited context, mainly being attributed to the inherited development level, and infrastructural capacities of cities to accommodate the needs of migration flux, as well as their institutional maturity to manage rapid urban changes.

\footnotetext{
${ }^{55}$ Kosovo Environmental Protection Agency (KEPA), Report on Environmental state 2006-2007, pp.. 20
} 

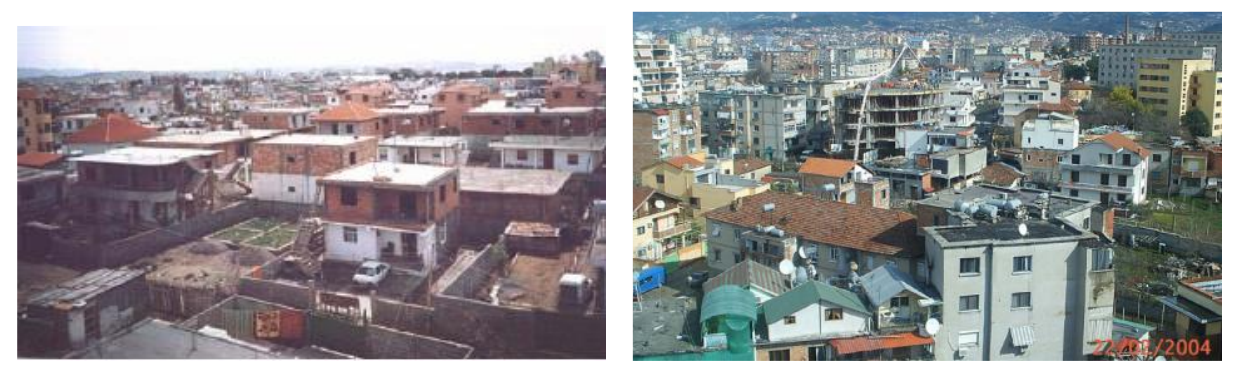

Figure 5. Informal settlements in the outskirts and unplanned densification of the inner-city in Tirana (from left to right) 56
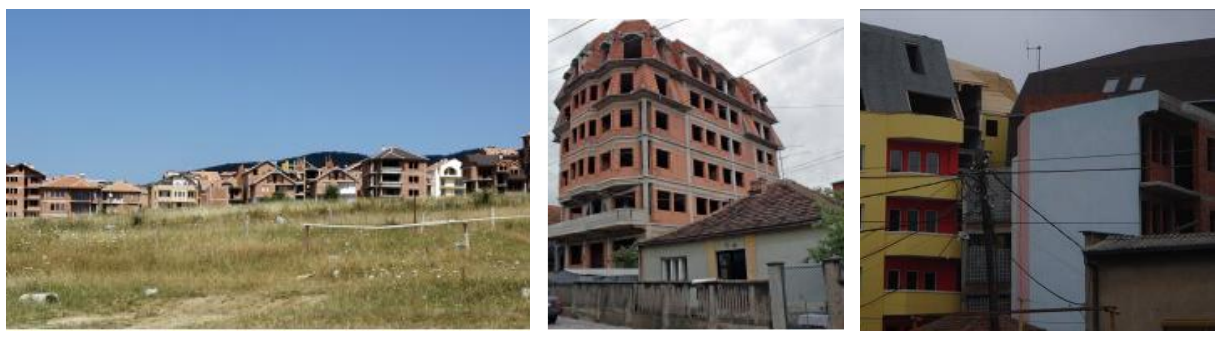

Figure 6. Unchecked development in the outskirts and densification of the inner-city through illegal buildings in Prishtina (from left to right) ${ }^{57}$

While the Adriatic coastline is experiencing new spatial metropolitan-rural interaction and the public space is suffering as a result of this development process ${ }^{58}$, Tirana (Figure 5) and Prijedor are struggled with consequences of newly formed informal settlements in public land ${ }^{59}$, and Prishtina (Figure 6), Belgrade and Sofia with buildings erected without construction permit ${ }^{60}$. On the other hand, Bucharest ${ }^{61}$ is challenged by collective dwellings built in the socialist times, which today are in a critical state in terms both of their structure and their social function, and Skopje with building of a new image of the city, through the plan for city center 'Skopje until 2014', which has been criticized as an improper neo-nationalistic plan ${ }^{62}$. Adding to all this the issue of privatization of public space and facilities, which is shrinking and transforming the space in cities, SEE countries are kept in between anticipated modernization/Europeanization trends in one hand, and factual fragmental transformation of urban space.

The end result of such transformations in cities and their outskirts is a pattern of unsustainable development. Urban solutions for that matter are needed for each local context, while looking at possibilities to replicate solutions in both, national and regional terms. In this context, initiatives to document the trends of urban transformation and research scenarios for improvement of urban situations in cities have proved to be helpful in the sense that they provide the ground for collaboration and transfer of knowledge among professionals and decision-makers throughout the region.

\footnotetext{
${ }^{56}$ From the experience of Co-Plan, an NGO in Albania: presentation in the Archis workshop on illegal buildings in Prishtina in 2007 (see more about Co-Plan in http://www.co-plan.org/)

${ }^{57}$ From the experience of Archis Interventions: presentation in the Archis workshop, 2007

58 See Archis SEE Network: http://www.seenetwork.org/activities/177/

${ }^{59}$ Analysis of the members of Urban Planning Task Force of the Network of Associations of Local Authorities of South-East Europe(NALAS)

60 Discussion / presentation of case studies; Conference “Operacija Grad 2008” Zagreb.

${ }^{61}$ See: Archis SEE Network: http://www.seenetwork.org/activities/177/

${ }^{62}$ Ibid. The vision for city centre Skopje available in: $\mathrm{http}: / / \mathrm{www}$.youtube.com/watch?v=YBYtmAOt7RI
} 
Among initiatives that involve urban transformation facts and solutions discussed in this paper are those launched by the Network of Associations of Local Authorities of South-East Europe (NALAS) and the Archis SEE Network. The knowledge gained about urban issues in the region as a member of both networks, have made possible for me to expand the initiated strategies for urban regeneration in Prishtina (started in late 2006) resulting in formal cooperation with the city administration, as well as in dissemination about the process and practices, to the local authorities is SEE.

\subsection{Network of Associations of Local Authorities of South-East Europe (NALAS)}
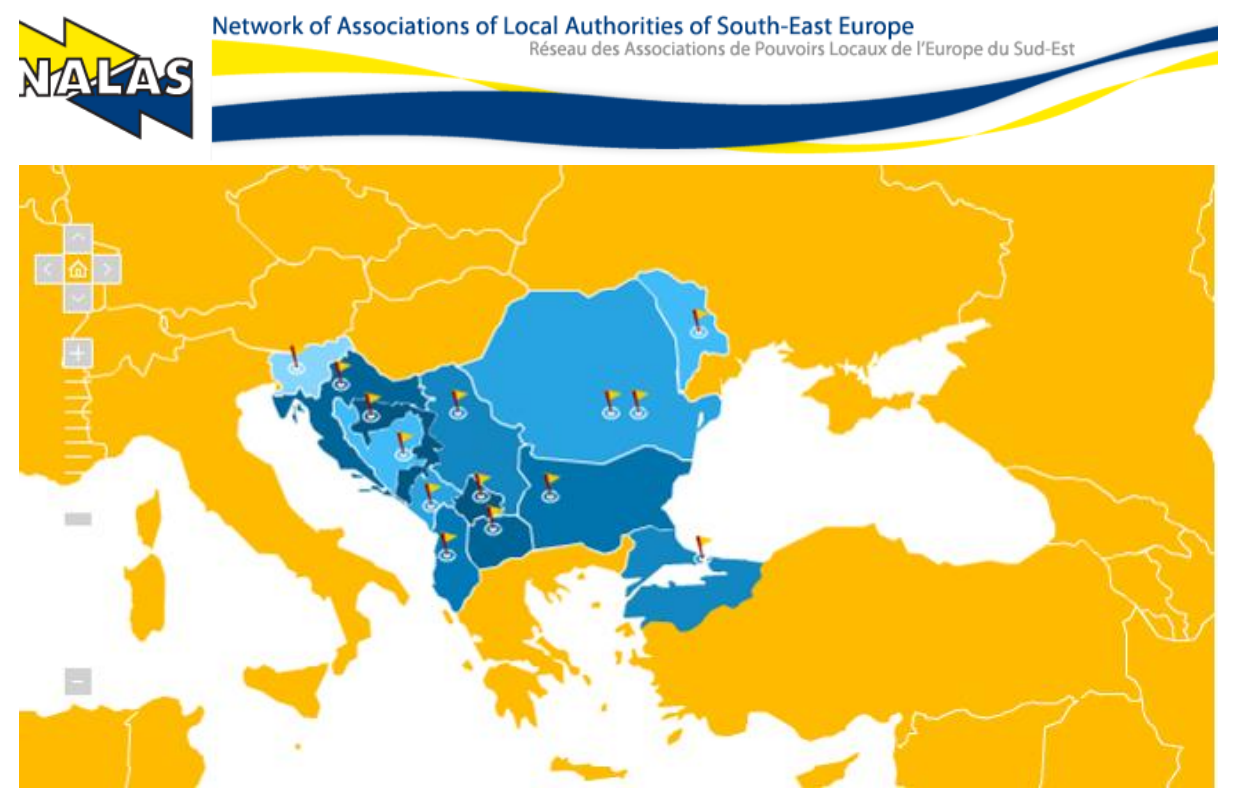

Figure 7. Map of NALAS members (source: http://nalas.eu)

NALAS is a network which currently unites 15 full members from South-East Europe. At the heart of NALAS are the Task Forces which bring together experts from the region, competent association staff and professionals employed in the local government administration. The Task Force for Urban Planning tackles the issues common in the region, such is integration of informal settlements, inclusion of more stakeholders in the urban planning process and collection and analysis of the right parameters in what is known as 'urban economics'. ${ }^{63}$ Common challenges identified by this Task Force during its meeting sessions since 2009 are generally associated with law enforcement. While urban planning legislation in NALAS member countries are drafted against the European legislation model, provisions that regulate instruments for implementation of urban plans and their management are still being devised. Hence, the identified 'common challenges' (Table 1) were analyzed against individual contexts and were used to lay the ground for common recommendations and model projects for the member associations.

Table 1: Common challenges in $\mathrm{SEE}^{64}$

\footnotetext{
63 http://nalas.eu/taskforces.aspx , and http://nalas.eu/up/about.aspx

64 Working document: "Common Challenges" (2009)available online for members in NALAS Knowledge Tree (document management system)
} 


\begin{tabular}{|l|l|}
\hline 1 & Poor or incomplete planning framework; \\
\hline 2 & $\begin{array}{l}\text { Slow planning processes, not very sensitive to development } \\
\text { needs; }\end{array}$ \\
\hline 3 & Negligence in enforcing existing laws \\
\hline 4 & $\begin{array}{l}\text { Considerable number of informal settlements due to wars, } \\
\text { political tensions or non- enforcing existing laws; }\end{array}$ \\
\hline 5 & Poor participation of affected parties in the planning processes; \\
\hline 6 & Unresolved land and property ownerships; \\
\hline 7 & Poor planning approaches and methodologies; \\
\hline 8 & $\begin{array}{l}\text { Insufficient identification and utilization of potentials, provision } \\
\text { of specific economic infrastructure, optimization of land-use and } \\
\text { development. }\end{array}$ \\
\hline
\end{tabular}

As it may be noted from the table above, there are evident problems in urban planning and management issues in SEE countries, which require determination of the local authorities to address the gaps in respective legal frameworks and intervention instruments, In this endeavor, NALAS initiated comparative analysis in the different member associations and resulted with the project and the subsequent publication entitled "The Legislation and analysis of the implementation of spatial and urban planning in Albania, Kosovo, Macedonia, Moldova, BiH and Turkey as compares to the case of Denmark". Recommendations that were drawn through this initiative are used to develop specific recommendations for improving relevant national legislative frameworks (Table 2). This process of analysis and introduction of refreshed common recommendations is furthering in yearly basis with integration of other member states in the NALAS network. 
Table 2. General Recommendations arising from the NALAS analysis ${ }^{65}$

\begin{tabular}{|c|c|}
\hline 1 & $\begin{array}{l}\text { cal governments }[\ldots] \text { need to }[\ldots] \text { continue with more intense } \\
\text { al government reforms, especially in the area of spatial and } \\
\text { oan planning }\end{array}$ \\
\hline 2 & $\begin{array}{l}\text {... governments are obliged to provide conditions for sustainable } \\
\text { development of communities[...] to satisfy the needs for the } \\
\text { social and economic prosperity }\end{array}$ \\
\hline 3 & $\begin{array}{l}\text { The procedures for adopting plans shall be simplified, }[\ldots] \text { the } \\
\text { issuance of the necessary authorizations need to be done in a } \\
\text { timely fashion ... }\end{array}$ \\
\hline 4 & $\begin{array}{l}\text { The legal framework should be adapted to transfer the right of } \\
\text { ownership and management of non-private land }[\ldots] \text { legal } \\
\text { compensation mechanisms should then be implemented for } \\
\text { owners of property subject to expropriation ... }\end{array}$ \\
\hline 5 & $\begin{array}{l}\text {... a greater degree of fiscal decentralization }[. . .] \text { to gather } \\
\text { sufficient financial means to fund the expansion of new spatial } \\
\text { and urban plans and to amend existing ones. }\end{array}$ \\
\hline 6 & $\begin{array}{l}\text {... adopt complementary laws regulating spatial and urban } \\
\text { planning, }[\ldots] \text { establish a clearly defined hierarchy of plans. }\end{array}$ \\
\hline 7 & $\begin{array}{l}\text { The procedures for receiving consent for plans from higher levels } \\
\text { of authority should be better regulated and respected. ... }\end{array}$ \\
\hline 8 & $\begin{array}{l}\text { The type, content and direction of plans should be determined by } \\
\text { relevant laws and by-laws [...]. Frequent law amendments shall } \\
\text { be avoided since it creates legal insecurity. It is recommended } \\
{[\ldots] \text { to adopt four to six year municipal development plans, while }} \\
\text { urban plans should be valid for longer periods ... }\end{array}$ \\
\hline 9 & $\begin{array}{l}\text {... high quality spatial and urban plans }[\ldots] \text { created by } \\
\text { authorized public agencies and licensed companies. [...] avoid } \\
\text { the danger of monopolization of the market ... }\end{array}$ \\
\hline 1 & ... officers directly involved in servicing the citizens $[\ldots]$ shall \\
\hline 0 & $\begin{array}{l}\text { be trained to deliver high quality services in regard to spatial and } \\
\text { urban planning ... }\end{array}$ \\
\hline 1 & of the means of mo \\
\hline 1 & ation of the plans, $[\ldots]$ \\
\hline $\begin{array}{l}1 \\
2\end{array}$ & $\begin{array}{l}\text { Citizens' and other stakeholders' participation is of vital } \\
\text { importance from the very beginning of the planning process. [...] } \\
\text { municipal councils should adopt practices for submitting urban } \\
\text { plans in two phases following public discussion. }\end{array}$ \\
\hline $\begin{array}{l}1 \\
3\end{array}$ & $\begin{array}{l}\text { Issuing extracts from detailed urban plans, gathering } \\
\text { qualifications and conditions, and building permits shall be under } \\
\text { local government's competence ... }\end{array}$ \\
\hline $\begin{array}{l}1 \\
4\end{array}$ & $\begin{array}{l}\text { In all phases of planning, intangible cultural heritage shall be } \\
\text { protected. [...] it is necessary to build a sustainable system for } \\
\text { the conservation, restoration and reconstruction of facilities } \\
\text { protected by law ... }\end{array}$ \\
\hline 1 & Illegally built facilities and illegal settlements $[\ldots]$ shall be \\
\hline
\end{tabular}

\footnotetext{
${ }^{65}$ The table is a simplified form of presentation of general recommendations provided in the document "TheLegislation and analysis of the implementation of spatial and urban planning..." developed for the purpose of this paper.
} 
5 legalized and integrated. [...] relevant laws and by-laws shall be adopted $[\ldots]$ separately and independently from the planning

law.

First two recommendations on the local government role suggest that countries need to continue with more intense reforms, especially in the area of spatial and urban planning, as they are obliged to provide conditions for sustainable development of communities. In other words, the ongoing decentralization process, including fiscal decentralization should generate mechanisms and means that would enable to meet the needs for the social and economic prosperity. The set of recommendations concerning legal framework on implementation of urban and spatial plans suggest complementation by new laws and by-laws that regulate ownership, illegal settlements and illegally built facilities, as well as protection of cultural heritage sites. The problem of ownership and illegal development has been commonly acknowledged by NALAS members as the most striking issues that need urgent attention and regulation. Another concern identified as to being problematic in maintaining proper planning and monitoring system is the frequent changes to the legislation concerning the type, content and direction of plans. Such change appeared in Slovenia during the period of application for EU candidature and is likely to apply for future EU candidate member states from the region. This transition in the legal framework in the case of Slovenia has caused abruption and continuous revision to the planning documents, hence the lesson learnt from this case should be considered and European planning provisions should be addressed simultaneously while amending or drafting new laws and by-laws in countries awaiting EU membership. The quality of plans and public participation in the planning process are also critical in many countries, as it is the quality of services delivered by the planning authorities. In this context, urgent need for improving municipal capacities and creating competent planning authorities is addressed by NALAS members. Lack of will, transparency and capacity to proceed with planning permits and deliver services to the citizens, have produced a counter-effect and intensified illegal building activities, as well as unfriendly environment for domestic and foreign investments. This case is in particular present in Prishtina.

The NALAS cooperation projects have proven to be important as they directly involve local authorities, whose performance is crucial to the future planning systems. In this context, regional initiatives play an important role in creation of the grounds for faster and more equitable socioeconomic development and securing improved standards of living in South East Europe.

\subsection{Archis SEE Network}

"The task of creating a sustainable urban environment and maintaining architectural values cannot be left entirely to local authorities and international organizations: civic society stakeholders also have a crucial role to play. Artistic interventions, political lobby groups and independent initiatives launched by architects and urbanists have already redrawn the boundaries of urban development: sustainable concepts from and for the community, are now irrevocably on the political agenda." (http://www.seenetwork.org/about/) 


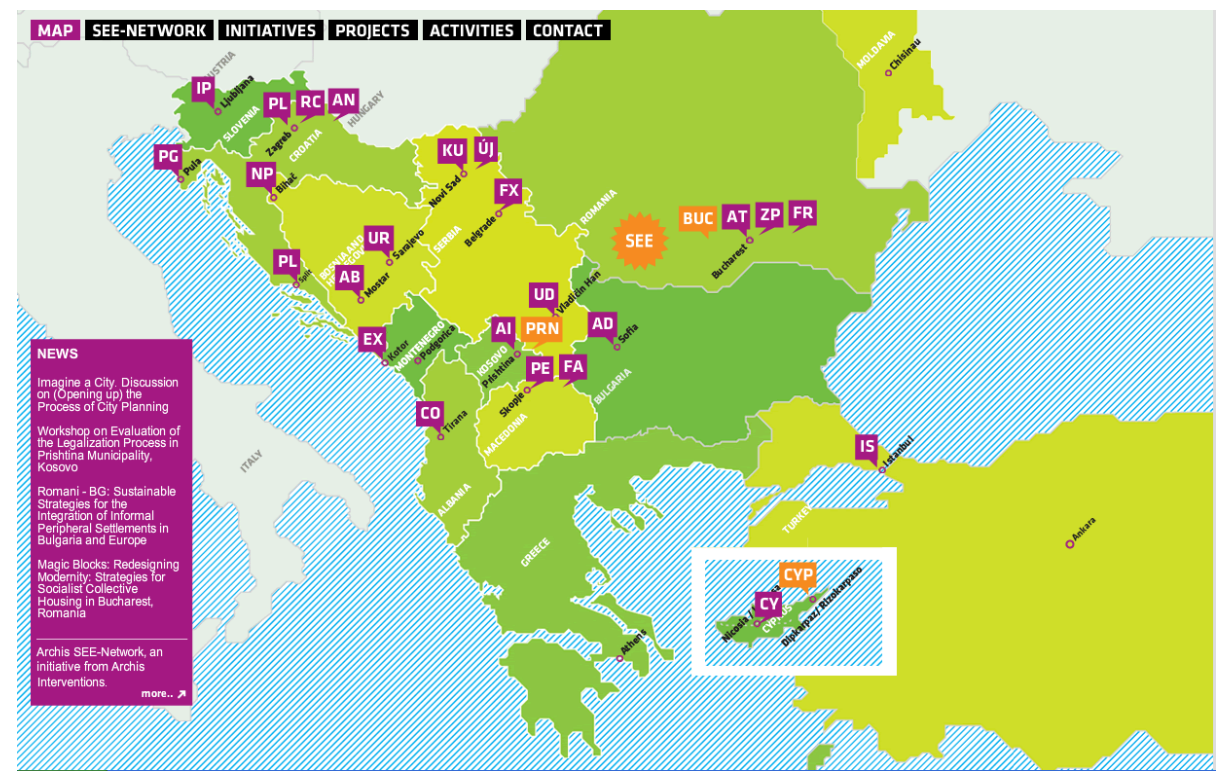

Figure 8. Map of Archis SEE Network (source: http://www.seenetwork.org/)

Activism and independent initiatives of architects, urbanists, artists, sociologists and other professionals from the civil society and academia has become quite noted in the region. The idea to bring together these initiatives within Archis SEE Network (created in 2008) has made possible the exchange of knowledge and best practices in coping with various political and social dimensions of the urban environment, as well as to integrate the issues discussed in international discourse on urbanism. About 25 local initiatives have made their projects available through this network, and have gained a wider audience in SEE and beyond. In doing so, local initiatives have maid possible the exposure of their findings about trends and challenges of urban transformation in local level, as well as their involvement in regional projects.

The criticism about urban occurrences in SEE coming from the civil society plays and important role in relevant information exchange and in shaping opinions about the context of transition in SEE countries, and the challenges they deal with, in the process of internationalization. Further more, their active involvement in devising solutions for certain urban issues in local level that may apply in a wider regional context, have raised the awareness of developing agencies and professionals from other parts of Europe about the complexity of urban development issues and the need to address the SEE context within the context of Europe as a whole.

Among local initiatives that gained attention of the international discourse through documenting informal building trend in the post-war context and providing strategies and problem solutions, is based in Prishtina.

\section{Strategies for urban interventions in Prishtina}

The city of Prishtina is a case of enormous post-war urban transformation. Despite of the high presence of international organizations and their direct involvement in the overall rebuilding and democratization of the country after the war in 1999, negligence towards urban development was exceptional. The very start of the postwar period corresponded with the needs of population for shelter. In a due course, the needs to upgrade living conditions grew, and in addition to this, the needs of the international community for residential and office space in the capital city required ad-hock solutions. The aforementioned needs provoked a private building boom in substantial and sensitive fragments of the city, which overwhelmed capacities of the city administration in 
terms of both, urban policies and urban development. Therefore, the need to address the booming phenomena from an independent professional stance became evident.

Projects that involve documentation of descending urban trend in the city were initiated in cooperation with European partners ${ }^{66}$ and were jointly developed with regional partners and the local administration in Prishtina. Urban analysis and strategies devised through the local initiative were adopted by the municipality of Prishtina and the model of intervention in Prishtina's case was disseminated and considered by the SEE local administrations' network.

\subsection{Study on the prototypes of illegal buildings ${ }^{67}$}

The complexity of the urban situation in Prishtina was explored and analyzed in a study through which prototypes of illegal buildings were identified. The so-called 'Urban Pathology Map of Prishtina' generated from this study aimed at drawing the attention to the general public, on the pattern of unchecked urban development in the post-war context.

An inventory of consequences arising from the problems of uncontrolled construction was developed, and on the basis of the analysis of prototypical ('pathological') areas, four prototypes of uncontrolled construction were identified (see Fig. 9, Table 2):

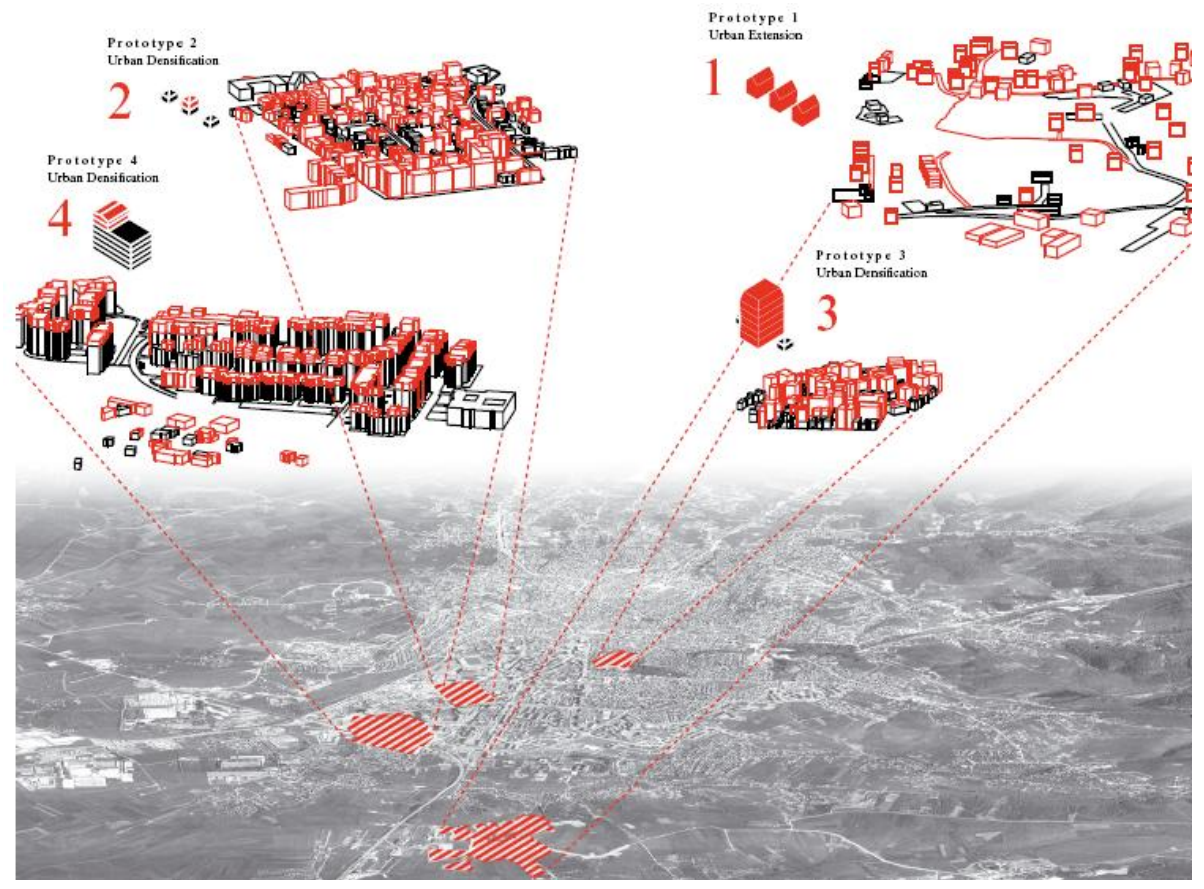

Figure 9. Study on Prishtina: prototypes of illegal buildings (illegal buildings constructed after 1999 are indicated with red color)

Table 3. Prototypes of illegal buildings in Prishtina

\begin{tabular}{|l|l|}
\hline Prototype 1 & $\begin{array}{l}\text { Single-family houses which are built in the outskirts of } \\
\text { the town, where the building owners own the land and } \\
\text { permission is generally not applied for nor granted. }\end{array}$ \\
\hline Prototype 2 & Single-family houses located inside the city; building \\
\hline
\end{tabular}

\footnotetext{
${ }^{66}$ The local NGO Archis Interventions Prishtina was founded in 2005 as part of the Archis network, together with Archis Interventions Amsterdam and Archis Interventions Berlin. Aut hor of the paper is a co-founder/manager of the Prishtina branch.

${ }^{67}$ The document is available in: http://www.seenetwork.org/projects/28/ . Downloadable in: http://www.seenet work.org/files/2010/11/16/2/Archis\%20Interventions The\%20New\%20Prishtina 2007.pdf
} 


\begin{tabular}{|c|c|}
\hline & $\begin{array}{l}\text { owners own the land and are usually part of the } \\
\text { neighborhood community; owners generally doesn't } \\
\text { seek the permission and build with maximal use of } \\
\text { space, without consideration to the plan limitations. }\end{array}$ \\
\hline Prototype 3 & $\begin{array}{l}\text { Buildings which also have maximal use of space, both } \\
\text { in site occupancy and height, and are built for } \\
\text { commercial purpose, hence, not for their own need } \\
\text { (flats, offices etc) In this case, the developer are } \\
\text { usually not part of the neighborhood community and } \\
\text { builds without seeking permission and without } \\
\text { consideration to the plan limitations. }\end{array}$ \\
\hline 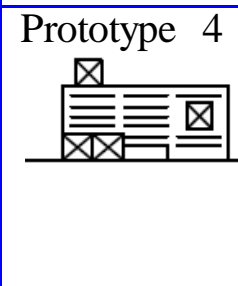 & $\begin{array}{l}\text { The fourth prototype - the urban parasites - groups the } \\
\text { roof extensions, annexes, cuts into buildings and } \\
\text { houses on roofs, which are mainly built by individual } \\
\text { developers for the extension of family flats. The space } \\
\text { developed in this way is public and permission is } \\
\text { generally not applied for nor granted. }\end{array}$ \\
\hline
\end{tabular}

In addition to the qualification of the given prototypes, the study provides strategies for their treatment, as a tool to devise a road-map for future intervention. The strategy concept worked out late 2006 was furthered on with concrete study cases, which were developed with students of architecture in 2007 (Fig. 8). The strategy concept was acknowledged by the local administration in 2007 and became part of the Prishtina City Program for years to follow. Also, the networking strategy suggested in the study on Prishtina aimed at testing results of this study in a regional context, which resulted positive two years later, with the creation of the Archis SEE Network in 2008.

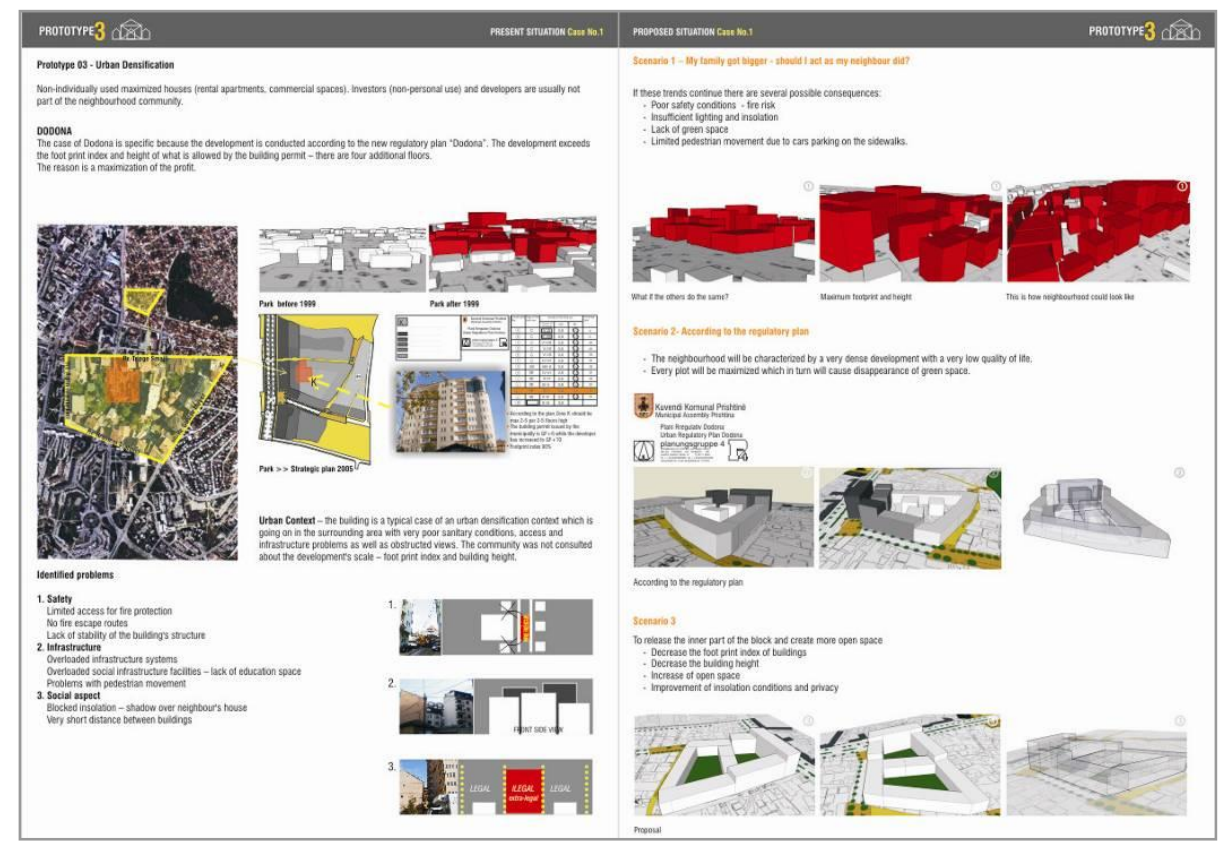

Figure 10. Case study of prototypical areas: analys is and urban solutions ${ }^{68}$; (from workshop and exhibition with students of architecture in 2007)

${ }^{68}$ from the brochure: "Future of the City-City of the Future: Prishtina-Berlin-Paris", 2007 


\subsection{The Manual on legalization ${ }^{69}$}

The implementation strategy for treating illegal buildings in Prishtina was developed in 2009 by local, regional and international experts, in cooperation with representatives of the Municipality and other official organizations in Kosovo. The result of this cooperation is the "Manual" on legalization, which brought policymakers in Kosovo into closer contact and cooperation with regard to the legalization issue. The "Manual" lays down the principles relating to security, infrastructural networks and social aspects, etc., that are necessary to improve the urban situation in Prishtina. It also provides recommendations to the Municipality of Prishtina about the process, timelines and conditions that are necessary to consider during the legalization process. The "Manual" was adopted by the Municipality in the same year as part of the Municipal regulation for legalization, and the related principles became formal criteria for legalization. The second part of the document that involved recommendations for the Municipality was fully integrated in the aforementioned regulation.

\section{B / Minimum distance - Fire protection}

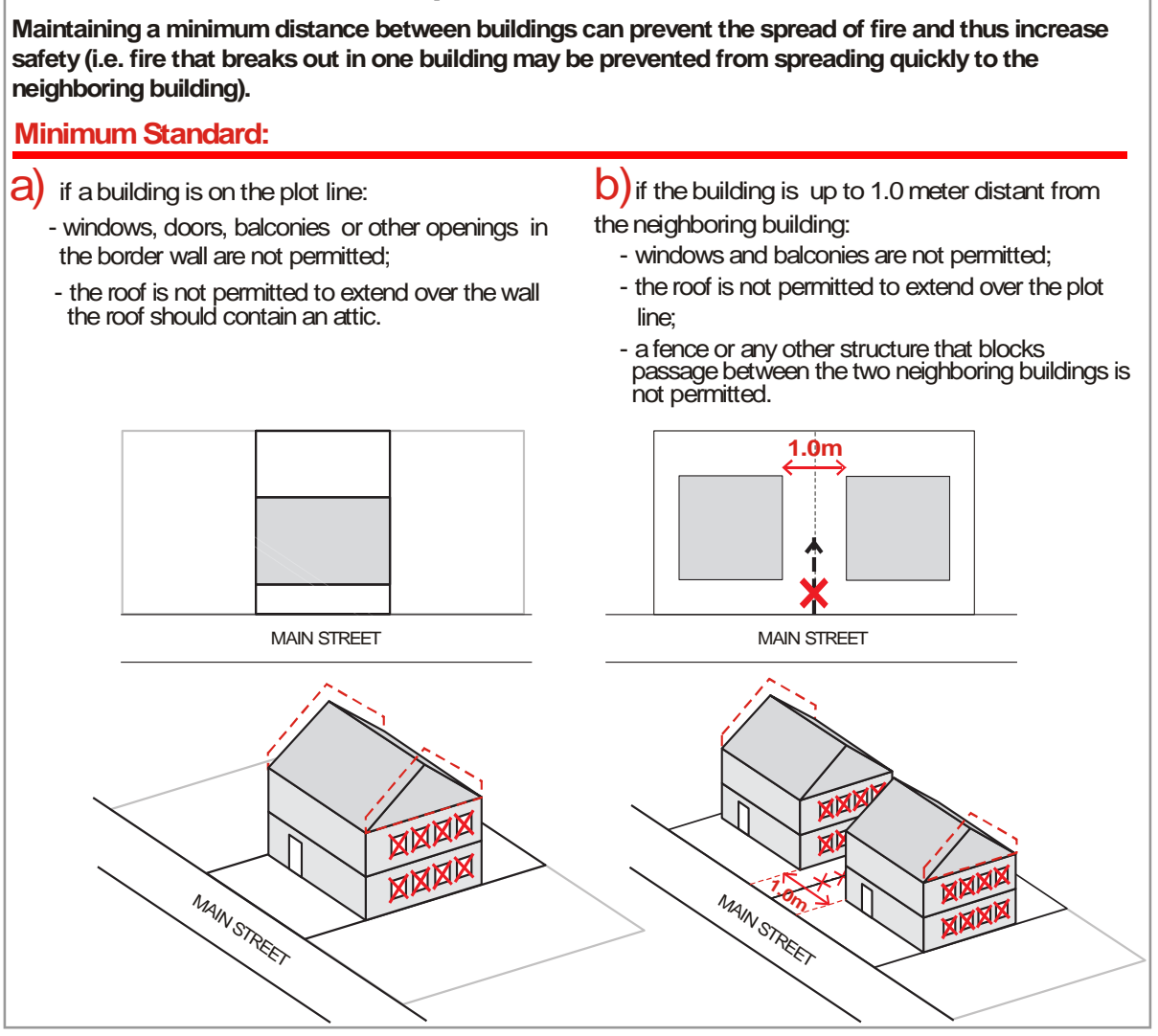

Figure 11. Minimum Standards for legalization. (Insert from the "Manual" showing legalization criteria related to Minimal distances - fire protection)

The first part of the "Manual" is developed in the form of minimum standards for legalization. It outlines basic guidelines with regard to security standards, social aspects and infrastructural needs.

The three issues were considered for three different prototypes $^{70}$ : buildings with max $450 \mathrm{~m} 2$ (which by law is the maximum area for a family house), buildings exceeding $450 \mathrm{~m} 2$, and

\footnotetext{
${ }^{69}$ Archis Interventions Prishtina (2009) Manual on Legalization. Document is available in: http://www.seenetwork.org/projects/28/ Downloadable in: http://www.seenet work.org/files/2010/1 1/16/3/Archis\%20Interventions Prishtina Manual 2009.pdf
} 
annexes to legal buildings. Minimum standards of security are developed with regards to Escape routes, Minimum distances - Fire protection, Structure (building's static) and Earthquake (build ing's dynamic) (Fig.11). The social aspect takes into consideration the Relations between neighbors (Interference, e.g. blocking of views or light, and Occupation of a neighbor's plot) and Relations between individuals and the neighborhood (occupation of public space), whereas the chapters on infrastructure (technical and social) affirms the need for developing the process of negotiation between the Municipality and the neighborhood.

The second part of the "Manual" is developed in the form of general recommendations for the Municipality of Prishtina on the legalization process. It addresses phases of the process and institutions that are necessary to functionalize for implementation of legalization.

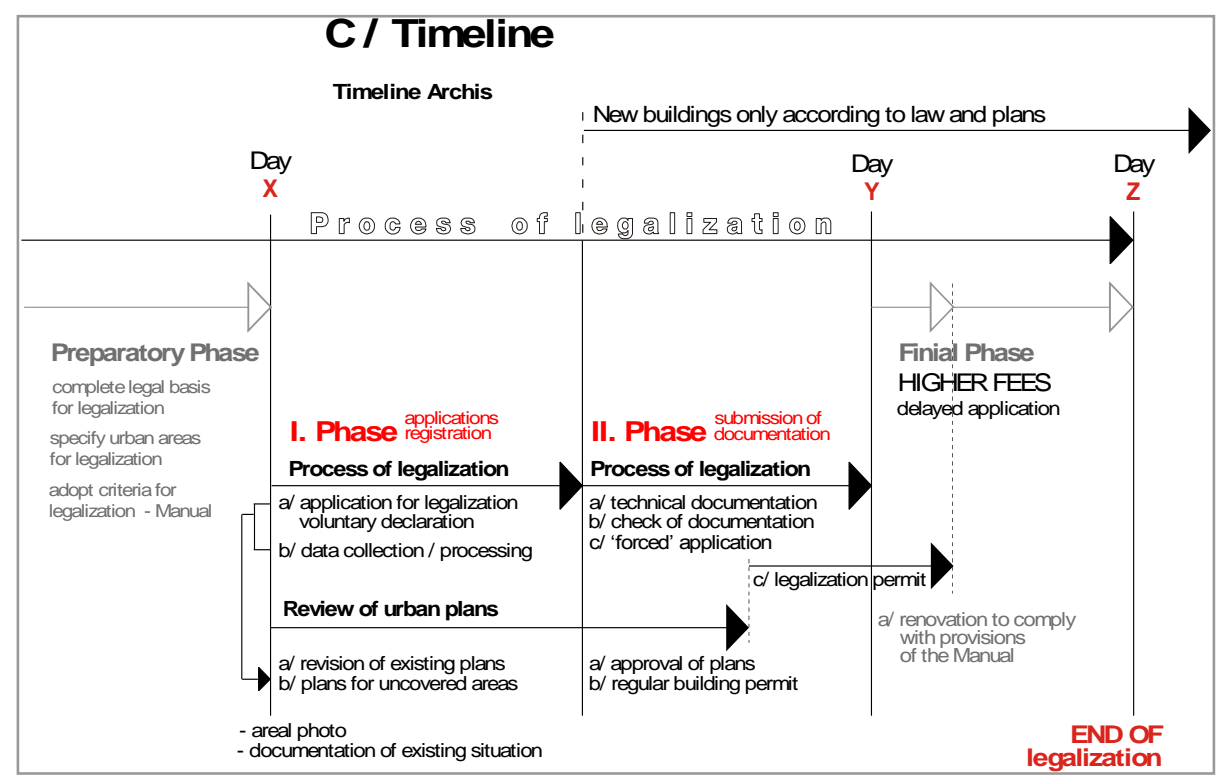

Figure 12. Process of legalization in Prishtina. (The Timeline showing the phases of the process of legalization )

In July 2009 the Municipality of Prishtina used the fundamentals of this concept to pass a resolution to start the legalization process. First phase of the legalization process, implying the registration of informal building, was finished in end 2010. About 7000 applications for legalization were submitted by the citizens of Prishtina and were processed accordingly.

\subsection{Legalization versus planning ${ }^{71}$}

The challenge that needed further attention was harmonization of the legalization process with the ongoing process of urban planning process. In other words, legalization of individual structures affect urban plans, in which case plans need review and adjustment to the situation on the ground, to the point that the general planning principles are not compromised. On the basis of this discussion, the recent study aimed to bring examples of selected sites in Prishtina (neighborhoods Dodona and Tophane) in order to illustrate problematic aspects of the legalization process, as well as to give potential solutions in terms of application of two sets of criteria in the very urban blocks - legalization standards in one hand and the regulatory plan's criteria on the other hand.

\footnotetext{
${ }^{70}$ Three approved prototypes generated from the concept of four prototypes discussed in the previous chapter, in order to comply with definition of buildings set forth in the Law on Construction.

${ }^{71}$ Archis Interventions Prishtina (2011). Legalization Permit vs. Planning Permit.
} 


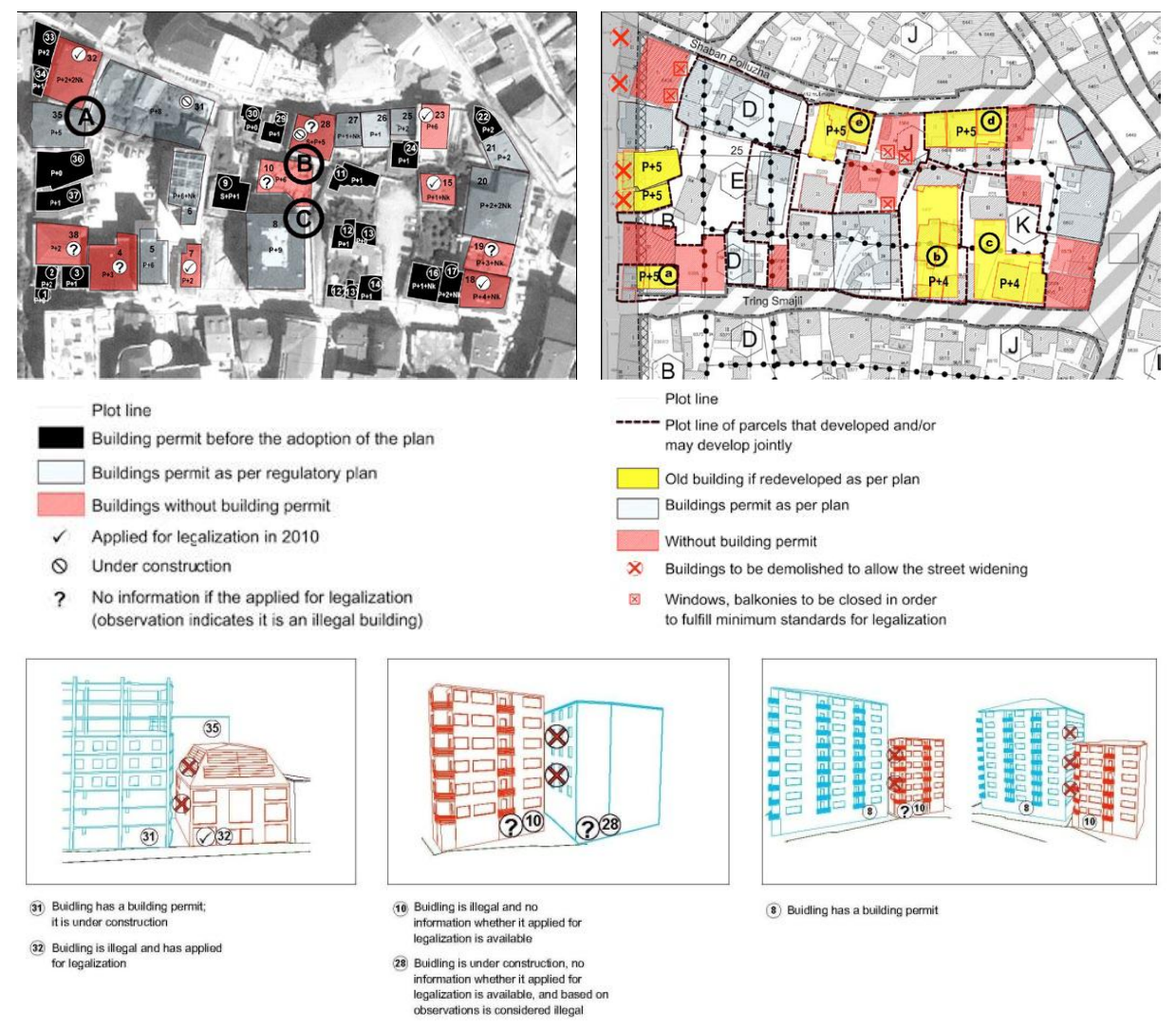

Figure 13. Case study Dodona (top left: map showing the status of buildings in October 2011 with regards to legalization; top right: map showing possible solution in implementing both, planning and legalization parameters; bottom: interpretation of minimum standards for legalization for identified problems)

\subsection{Study on Prishtina's future development ${ }^{72}$}

Complementary to the concept strategy on legalization, discussions on the future perspective of Prishtina were initiated through a study that promotes realistic strategy, which takes the current situation into account but also establishes the principles of viable future development. The study entitled "Prishtina - Dynamic City" developed a key concept on city's potential as the capital of Kosovo, and identified knowledge and education as the key factors for its future development. It also focuses on the latter's spatial implications and formulates major development directions. The first section of the study discusses the planned development in the light of urban situation mapped in 2009 and the adjusted requirements since the urban vision was produced in early 2004. This concept was soon adopted by the Mayor of Prishtina, and after the elections in late 2009 became part of the "Program for Governance of Prishtina 2010-2013" (Fig. 14).

${ }^{72}$ Archis Interventions Prishtina (2009) Prishtina- Dynamic City. Downloadable in: http://www.seenetwork.org/files/2010/11/18/4/AI\%20Prishtina Dynamic City Study 2009.pdf 


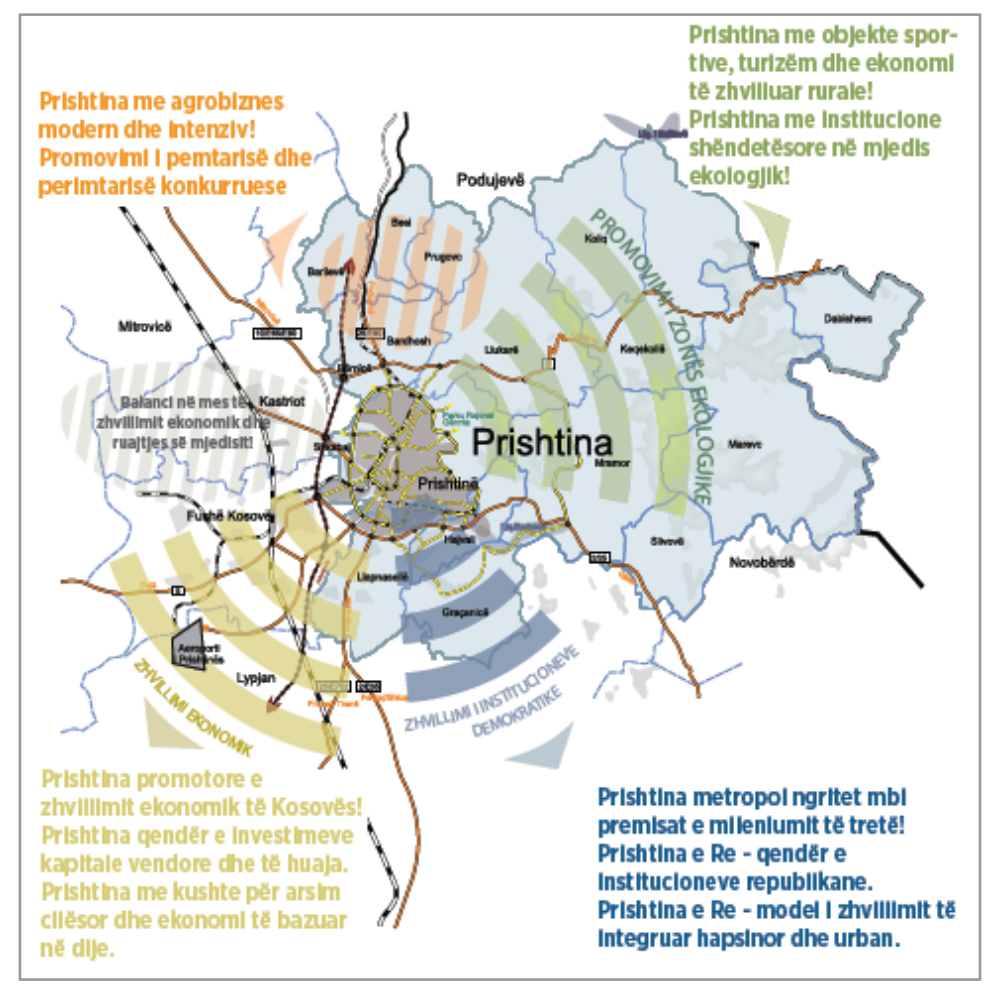

Figure 14. Prishtina political vision 2010-2013 ${ }^{73}$ (strategic map reflecting spatial development directions)

The second part of the study "Future Perspective" inserts that the potential of Prishtina as a young capital, as compared to other capitals in the region, is its youth, given that the average age of Kosovo's population is around 23 years, which ranks Kosovo's population amongst youngest population in Europe. A focus on education and knowledge, therefore, was identified as the biggest potential for future perspective of Prishtina. In this context, the study provides possible solutions for spatial integration of highly significant symbolic spaces in the city representing History, Nation, Education and Economy, through introduction of specific catalysts that aim at improving the urban situation, especially in the inner city, and the future of the knowledge based-economies.

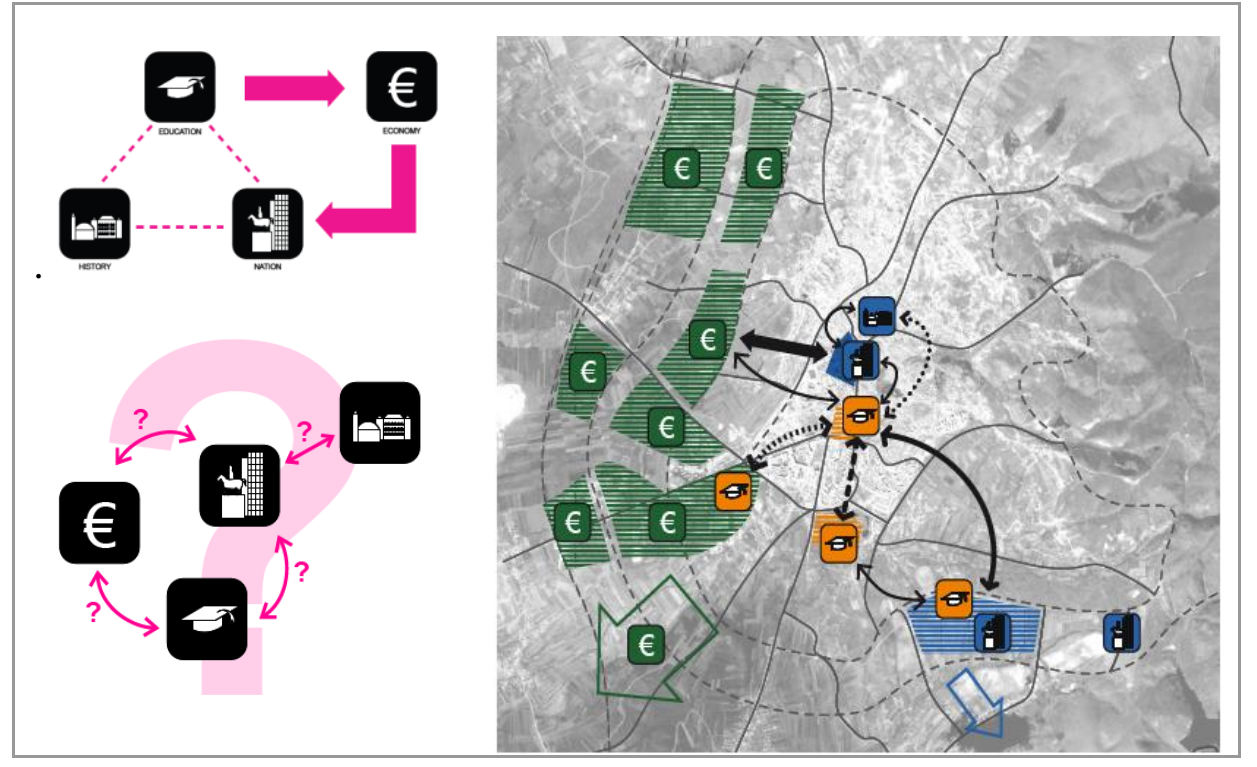

\footnotetext{
${ }^{73}$ The author of this paper is also the aut hor of the map, produced during the electoral campaign for Prishtina Mayor in October 2009.
} 
Figure 12. Analysis of spatial integration of symbolic spaces in Prishtina (Integration of strategic areas reflecting spatial development directions)

As the capital city of Kosovo, with a vision to develop economic, transportation and social opportunities for a larger region encompassing five surrounding municipalities, as well as adjusting its economic policies to suite the global market trends, Prishtina is heading towards fine-tuning its features with the global development of the new millennium.

\section{Conclusion}

It is evident from the study that, the SEE region is facing multiple transformations which have commonly been identified as common challenges of the new era. The context of the postsocialist and post-war associated with unmanaged growth in which the built environment was shaping during the last decades, have affected the cities' structures in a negative way and the perception about their future prospect. This has also been identified through documentation of local cases of urban transformations by regional initiatives such are NALAS and Archis SEE Network. Studies and recommendations produced through regional networking highlight the need for taking adequate steps in fostering the legal framework and complementary implementation mechanisms. In this endeavor, SEE countries would need to consider that further negligence and/or disturbance of their physical and cultural environments, would compromise their perspectives and competitiveness in EU and beyond. Among cases seeking urban solutions to the descending practices of city development is Prishtina, the capital of Kosovo. In order to achieve the aforementioned objective in Prishtina, the political will and a fostered planning administration is strongly needed. Also, the institutional commitment and the public awareness to treat the existing illegal buildings and their surrounding by means of qualification and successive and gradual transformation must be firm. There should be a common understanding that after the conclusion of this process, urban planning criteria should be the only criteria to apply. Although the legalization process has started in late 2010 in Prishtina, there is a high potential to miss the need for harmonizing this process with the process of urban planning. In order for this issue to be comprehensive, the situation in the ground should be seriously taken into account and revision of plans should produce sustainable solutions, to the point that the planning objectives are not compromised. In this respect, attention should be given to the development directions adopted by the municipality in 2010. In a shorter timeframe, urgent attention should be given to the fragmented inner-city areas in order to integrate the spatially fragmented spaces, which are highly symbolic and significant to Prishtina. To achieve this, specific catalysts such are public community centers, new pattern of student housing, and business incubators may be developed in areas identified as spatial hubs fur youth interactions. Through introduction of such new forms of architectural and urban structures especially in the inner city, Prishtina will develop the opportunities for future knowledge based-economies. In doing so, it will adjust its development policies to suite the sustainable development goals and global trends. 


\section{References}

\section{Publications:}

NALAS Task Force for Urban Planning (2009). The Legislation and analysis of the implementation of spatial and urban planning in Albania, Kosovo, Macedonia, Moldova, BiH and Turkey as compares to the case of Denmark. Publication website: http://www.nalas.eu/up/legalanalysis/index.aspx\#download

Archis Interventions (2007). The new Prishtina. Volume Magazine, edition 1. Amsterdam. 2007. p. 80-93; also available online: http://www.seenetwork.org/files/2010/11/16/2/Arch is\%20Interventions The\%20New\%20Prishtina 2007.pdf

Archis Interventions (2009) Manual on the legalization of structures built without construction permit; also available online: http://www.seenetwork.org/files/2010/11/16/3/Archis\%20Interventions_Prishtina_Manual_2 $\underline{009 . p d f}$

Archis Interventions (2009). Prishtina - Dynamic City. Knowledge and Education: key factors for future development of Prishtina; also available online: http://www.seenetwork.org/files/2010/11/18/4/AI\%20Prishtina Dynamic City Study 2009.pdf

Archis Interventions Prishtina (2007). City of the Future/ Future of the City: Prishtina-Berlin-Paris". (not available online)

Archis Interventions Prishtina (2011). Legalization Permit vs. Planning permit. Prishtina. (not available online)

Reports / documentation:

Municipality of Prishtina (2004). Strategic Plan - Urban Development of Prishtina 2004-2020+"

Municipality of Prishtina (2010). The Governance Program for Prishtina 2010-2013. also available online:

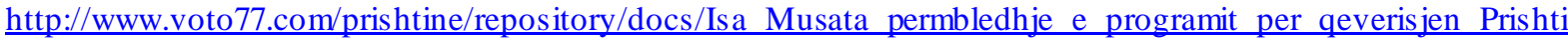
nes.pdf

Kosovo Agency for Protection of Environment (KEPA:2007), Report on the status of environment 2006-2007. Prishtina

WEB sources (dates accessed November 18-21, 2012):

http://nalas.eu http://www.seenetwork.org/

http://www.southeast-europe.eu/eu-enlargement/potential-candidates.html www.southeast-europe.net/en/ commons.wikimedia.org/wiki/File:Map_of_Southeast_Europe.PNG www.uni-graz.at/en/hare1www/hare1www the region.htm/ http://www.answers.com/topic/southeast-european-cooperation-process 